\title{
Viabilitas Benih Bawang Putih Varietas Tawang Mangu Setelah Penyimpanan pada Berbagai Suhu
}

\section{Viabilitiy of Allium sativum cv. Tawang Mangu Seed After Storage at Different Storage}

\author{
Sulassih ${ }^{1}$, Yohanes Aris Purwanto ${ }^{1,2}$, Sobir $^{1,3^{*}}$, Naekman Naibaho $^{1}$, Siaga Yudha Pratama ${ }^{2}$, Nurmalia ${ }^{2}$ \\ ${ }^{1}$ Pusat Kajian Hortikultura Tropika, LPPM IPB, Jl. Raya Pajajaran Baranangsiang, Bogor, Indonesia \\ ${ }^{2}$ Departemen Mesin dan Biositem, Fakultas Teknologi Pertanian IPB, \\ Jl. Lingkar Akademik Kampus IPB Dramaga, Bogor 16680, Indonesia \\ ${ }^{3}$ Departemen Agronomi dan Hortikultura, Fakultas Pertanian IPB, \\ Jl. Meranti Kampus IPB Dramaga, Bogor 16680, Indonesia
}

Diterima 24 September 2018/Disetujui 22 Oktober 2018

\begin{abstract}
Viability of garlic seed is important for seed quality. Periode of seed storage Penyimpanan benih berkaitan dengan viabilitas benih. Viability testing measured after storage at $0^{\circ} \mathrm{C}, 7^{\circ} \mathrm{C}$ and room temperate. Moisture content decreased (40$45 \%$ ) after 1 month in the storage under light condition, but the weight loss approximately at 1-8\%, still lower than ASEAN rules (2009) that is not over than 10-15\% for physical damage. Tawang Mangu variety showed higher for percentage of field emergence (83.33\%) after was storages at $0^{\circ} \mathrm{C}$ for one month and produced higher bulb (11 bulbs), but at the room temperature showed the lower for percentage of field emergence (56.94\%) and produced 2-3 bulbs. All the treatment $\left(7^{\circ} \mathrm{C}\right.$ and room temperature) produced small size of bulbs in weight $(1-2 \mathrm{~g})$, height $(1.5-1.7 \mathrm{~cm})$ and width $(1.5-1.6 \mathrm{~cm})$. Three of the temperature condition was produced single bulb called "bawang lanang", it suggested causing the land unfertilizer. Garlic was not suitable for medium land and high temperature such as Bogor.
\end{abstract}

Kata kunci : diameter, height, male garlic, small, weight

\section{ABSTRAK}

Viabilitas benih bawang putih menentukan terhadap kualitas benih. Penyimpanan benih berkaitan dengan viabilitas benih. Pengujian viabilitas benih bawang putih dapat dilakukan setelah perlakuan penyimpanan pada suhu $0^{\circ} \mathrm{C}, 7^{\circ} \mathrm{C}$ dan suhu ruang. Penurunan kadar air selama satu bulan di dalam ruang pendingin tanpa tutup plastik hitam (under light condition) dapat mencapai 40-45\%, sedangkan penurunan susut bobot mencapai 1-8\%, masih dibawah ketentuan ASEAN (2009) yaitu tingkat kerusakan fisik tidak boleh lebih dari 10-15\%. Varietas Tawang Mangu setelah penyimpanan di $0^{\circ} \mathrm{C}$ selama satu bulan menunjukan daya tumbuh tinggi (83.33\%) dan menghasilkan jumlah umbi lebih banyak (11 buah), sedangkan pada penyimpanan suhu ruang menunjukan daya tumbuh yang rendah (56.94\%) dan menghasilkan jumlah umbi yang sedikit (2-3 umbi). Kondisi umbi normal pada ketiga suhu menghasilkan ukuran umbi yang kecil dengan bobot 1-2 g, panjang umbi 1.5$1.7 \mathrm{~cm}$, dan diameter umbi $1.5-1.6 \mathrm{~cm}$. Penyimpanan $0^{\circ} \mathrm{C}, 7^{\circ} \mathrm{C}$ dan suhu ruang tetap menghasilkan bawang tunggal/bawang lanang, karena kondisi lahan yang kurang subur. Bawang putih kurang cocok ditanam pada dataran medium dan bersuhu tinggi seperti Kota Bogor.

Kata kunci : bawang lanang, bobot, diameter, kecil, panjang

\section{PENDAHULUAN}

Bawang putih adalah bahan makanan yang biasa dikonsumsi oleh masyarakat Indonesia. Bawang putih mengandung kalsium, fosfor, zat besi, vitamin dan bermanfaat sebagai anti diabetes, antihipertensi, antikolesterol, antioksidan, antimikrobia, serta antikanker (Hernawan dan Setyawan, 2003). Pasokan bawang putih pada tahun 2012 mencapai 90\% melalui impor, kususnya

\footnotetext{
* Penulis untuk korespondensi. e-mail: ridwanisobir@gmail.com
}

dari Cina yaitu sebanyak 410.100 ton dengan nilai Rp 2.27 triliun (Kementan, 24 Juli 2018). Pengurangan impor dilakukan oleh Kementerian Pertanian untuk swasembada bawang putih tahun 2023 (Kabar Bisnis, diunduh 3 Juli 2017). Percepatan swasembada benih dapat didukung oleh teknologi percepatan pertumbuhan benih bawang putih, karena benih bawang putih mengalami permasalahan yaitu dormansi selama 4-6 minggu setelah panen. Oleh karena itu perlu dilakukan evaluasi dalam percepatan perkecambahan benih melalui pematahan dormansi melalui penyimpanan dengan suhu $5^{\circ} \mathrm{C}$ sampai $10^{\circ} \mathrm{C}$ (Brewster, 2008). 
Viabilitas benih merupakan daya hidup benih yang dapat diindikasikan oleh pertumbuhannya ataupun gejala metabolismenya (Sadjad et al 1999). Viabilitas benih dipengaruhi oleh tiga faktor utama yaitu faktor induced, enforced, dan innate. Faktor induced adalah faktor yang berpengaruh selama benih yang terbentuk di lapang sampai saat pengolahan (benih siap ditanam). Faktor enforced adalah faktor-faktor dalam ruang simpan benih, sedangkan faktor innate adalah faktor genetik benih (Sadjad et al 1999). Uji viabilitas benih bawang putih varietas Tawang Mangu perlu dievaluasi setelah perlakuan penyimpanan di beberapa suhu.

\section{BAHAN DAN METODE}

Penelitian dilaksanakan di Laboratorium Pascapanen Pusat Kajian Hortikultura Tropika (PKHT), Institut Pertanian Bogor dan Kebun Percobaan Tajur PKHT LPPM IPB pada bulan Maret sampai dengan Juni 2018. Bahan yang digunakan umbi bawang putih varietas Tawang Mangu berasal dari Malang yang telah disimpan di petani 3 bulan setelah panen. Alat yang digunakan adalah pendingin merk Jet Frost, timbangan analitik, oven Memmerth, thermohygrometer, dan kamera. Pengujian viabilitas dilakukan pada dengan cara menanam hasil penyimpanan $0{ }^{\circ} \mathrm{C}, 7{ }^{\circ} \mathrm{C}$ dan suhu ruang selama satu bulan pada bedeng semai. Setiap perlakuan ditanam 24 umbi. Pengukuran kadar air dengan menggunakan rumus :

$$
(\%) \mathrm{KA}=\frac{(\mathrm{M} 2-\mathrm{M} 1)}{(\mathrm{M} 2-\mathrm{M} 3)} \times 100 \%
$$

Keterangan : KA adalah persentase kadar air, M1 adalah bobot cawan kosong sebelum oven, M2 adalah bobot cawan dan umbi sebelum di oven, dan M3 adalah bobot cawan dan umbi setelah di oven.

Pengukuran persentase susut bobot dengan menggunakan rumus sebagai berikut :

$$
(\%) \text { susut bobot }=\frac{(\mathrm{BB}-\mathrm{BK})}{(\mathrm{BB})} \times 100 \%
$$

Keterangan : BB adalah bobot awal sebelum penyimpanan, dan BK adalah bobot awal setelah penyimpanan.

Daya tumbuh benih dapat dihitung dengan menggunakan sampel berjumlah 25 butir dan diulang sebanyak 3 kali. Penghitungan daya tumbuh dengan menggunakan rumus :

$(\%)$ daya tumbuh $=\frac{\text { jumlah benih yang tumbuh }}{\text { jumlah benih yang ditanam }} \times 100 \%$

Penelitian diawali dengan menimbang dan dimasukan ke dalam kantong waring kemudian disimpan di dalam pendingin yang sudah diatur suhunya sesuai dengan perlakuan, dengan pintu lemari pendingin berkaca tidak ditutup dengan menggunakan plastik hitam (under light condition). Pengamatan pada penyimpanan meliputi susut bobot dan kadar air selama 1 bulan penyimpanan. Pengamatan di lapang meliputi daya tumbuh, tinggi tanaman, jumlah daun, jumlah umbi, bobot total umbi, jumlah umbi tunggal/umbi lanang, panjang umbi, diameter umbi, bobot per umbi dan jumlah siung per umbi.

\section{HASIL DAN PEMBAHASAN}

\section{Penyimpanan Dingin Pintu Tidak Ditutup Plastik Hitam (Under Light Condition)}

Kadar air awal simpan (0 BSS) mencapai 61-65\% dan mengalami penurunan untuk seluruh perlakuan selama penyimpanan 1 bulan hingga mencapai 41-45\% (Tabel 1). Kadar air benih mencapai kesetimbangan pada RH 19-27\% RH. Kondisi temperatur penyimpanan mencapai pada suhu $0{ }^{\circ} \mathrm{C}$ dapat mencapai suhu -2 sampai dengan $1.2{ }^{\circ} \mathrm{C}$ dengan RH $82 \%$, sedangkan perlakuan suhu $7{ }^{\circ} \mathrm{C}$ kondisi suhu mencapai 7-8.1 dengan $\mathrm{RH} \mathrm{41 \%} \mathrm{dan} \mathrm{suhu} \mathrm{ruang} \mathrm{mencapai}$ 29-31 ${ }^{\circ} \mathrm{C}$ dengan $\mathrm{RH} 46 \%$. Kondisi $\mathrm{RH}$ sangat tinggi pada penyimpanan $0{ }^{\circ} \mathrm{C}$, sedangkan pada penyimpanan $7^{\circ} \mathrm{C}$ dan suhu ruang menunjukan $\mathrm{RH}$ yang tinggi. Kondisi $\mathrm{RH}$ yang tinggi dapat menyebabkan kadar air benih menurun.

Penyimpanan dingin dengan kondisi ruang pendingin tidak ditutup plastik hitam menunjukan respon penurunan bobot umbi selama penyimpan 1 bulan pada perlakuan suhu $0{ }^{\circ} \mathrm{C}, 7{ }^{\circ} \mathrm{C}$ dan suhu ruang. Setiap benih bawang putih memiliki respon yang berbeda berdasarkan suhu penyimpanan (Volk dan Rotindo, 2004). Penurunan persentase susut bobot pada suhu $0{ }^{\circ} \mathrm{C}$ dibulan ke- 1 mencapai $1.08 \%$, pada suhu $7{ }^{\circ} \mathrm{C}$ mencapai $7.93 \%$ dan pada suhu ruang (29-31 ${ }^{\circ} \mathrm{C}$ ) mencapai $8.451 \%$ (Tabel 2). Penurunan tersebut dapat disebabkan oleh pengaruh cahaya sehingga dapat mempercepat penguapan/respirasi umbi. Pada penyimpanan umur 1 bulan belum menunjukan adanya kerusakan umbi seperti umbi berkecambah maupun kerusakan fisik akibat kering dan terkena serangan hama umbi rusak, meskipun perkecambahan dapat terjadi setelah 40 hari penyimpanan pada suhu $4{ }^{\circ} \mathrm{C}$ atau $2{ }^{\circ} \mathrm{C}$ dengan $\mathrm{RH} 80 \%$ (Resende et al., 2011) dan dapat terkena serangan jamur/cendawan pada penyimpanan dengan $\mathrm{RH}$ di atas 60\% (Medina dan Garcia, 2007). RH kritis untuk penyimpanan lama umbi bawang putih adalah di bawah 70\% (Brewster 2008). Adapun standar bawang putih berkualitas berdasarkan (1) bebas dari hama, (2) bebas dari kerusakan fisik, (3) tidak berkecambah dan (4) tidak berakar. Tingkat kerusakan fisik tidak boleh lebih dari 10-15\% (ASEAN 2009).

\section{Uji viabilitas benih}

Viabilitas benih merupakan daya hidup benih yang dapat diindikasikan oleh pertumbuhannya ataupun gejala metabolismenya (Sadjad et al 1999). Viabilitas Viabilitas benih bawang putih dapat diketahui melalui uji penanaman di lapang pada peubah persentase daya tumbuh. Bawang putih varietas Tawang Mangu menunjukan daya tumbuh 
yang maksimal setelah disimpan pada suhu $0{ }^{\circ} \mathrm{C}$ selama 5 bulan penyimpanan (Tabel 2). Pada perlakuan penyimpanan $0^{\circ} \mathrm{C}$ benih membutuhkan waktu simpan untuk siap ditanam di lapang. Perkecambahan dipengaruhi oleh suhu, ada atau tidak adanya masa dormansi, $\mathrm{RH}$, dan lamanya penyinaran (Hurtado et al. 2015). Bawang putih mengalami dormansi selama 4-6 minggu setelah panen. Pematahan dormansi dapat terjadi pada penyimpanan dengan suhu $5{ }^{\circ} \mathrm{C}$ sampai $10{ }^{\circ} \mathrm{C}$ (Brewster 2008). Aktivasi senyawa $\gamma$-glutamyl peptidase berperan terhadap pemecahan dormansi pada suhu $4^{\circ} \mathrm{C}$ (Ichikawa et al. 2006). Isoalliin meningkat pada suhu rendah akibat terdegradasinya $\gamma$-glutamyl peptides pada suhu rendah sehingga dapat meningkatkan aktivitas transpeptidase. Transpeptidase menstimulasi terjadinya pemecahan dormansi (Hughes et al. 2006).

Umbi bawang putih yang ditanam di lapang dan berumur 1 bulan (BST) memiliki daya tumbuh tertinggi pada penyimpanan suhu $0{ }^{\circ} \mathrm{C}$ mencaai $83.33 \%$, sedangkan pada suhu $7{ }^{\circ} \mathrm{C}$ memiliki daya tumbuh sedang $(77.77 \%)$ dan suhu ruang menunjukan daya tumbuh rendah yaitu $56.94 \%$. Viabilitas benih tinggi diindikasikan dengan daya tumbuh lebih dari $85 \%$. Peubah tinggi tanaman pada perlakuan suhu simpan $0{ }^{\circ} \mathrm{C}$ dan $7{ }^{\circ} \mathrm{C}$ varietas menunjukan pertumbuhan tinggi tanaman di atas $10 \mathrm{~cm}$, sedangkan pada suhu ruang di bawah $10 \mathrm{~cm}$ (Tabel 3). Karakter jumlah daun menghasilkan rata-rata 4 helai daun pada seluruh perlakuan.
Pemanenan dilakukan pada umur 3 bulan setelah tanam. Hasil panen untuk varietas Tawang Mangu menghasilkan umbi berukuran kecil dengan bobot di bawah 15 g per 24 tanaman dan beberapa menghasilkan umbi tunggal atau yang disebut bawang lanang (Tabel 4). Bawang lanang adalah umbi yang bermodifikasi karena lingkungan penanaman tidak cocok (Palungkun et al. 1993). Kondisi lahan di Kebun Percobaan memiliki pH asam yaitu 5.52, $\mathrm{N}$ total mencapai $0.21 \%$, C organik sebesar $2.23 \%$, Kalium sangat rendah $0.05 \mathrm{cmol} / \mathrm{kg}$. Kandungan $\mathrm{Fe}$ dalam tanah mencapai 67.95 ppm. Kondisi lahan di Kebun Percobaan Tajur memiliki kandungan Nitrogen, C organik, dan Kalium yang rendah dan kondisi tanah memiliki $\mathrm{pH}$ asam $(<6)$, sehingga pertumbuhan bawang putih kurang baik. Seluruh perlakuan penyimpanan $\left(0{ }^{\circ} \mathrm{C}, 7{ }^{\circ} \mathrm{C}\right.$ dan ruang simpan $)$ menghasilkan umbi berukuran sangat kecil. Ukuran tersebut dapat disebabkan karena kondisi tanah memiliki $\mathrm{pH}$ asam $(<6)$ sehingga kurang cocok untuk pertanaman bawang putih. Umbi yang dihasilkan memiliki ukuran yang sangat kecil yaitu panjang umbi $1.20-1.61 \mathrm{~cm}$, dengan diameter umbi 1.37-1.74 cm, bobot per umbi 1.20-1.78 g dan jumlah siung dalam setiap umbi rata-rata 3-4 siung (Tabel 5). Bawang putih dapat ditanam pada $\mathrm{pH}$ 6.5-7.0. Tanah yang terlalu asam dan terlalu basa menyebabkan pertumbuhan dan panen yang lambat.

Tabel 1. Persentase susut bobot perlakuan suhu penyimpanan $\left(0^{\circ} \mathrm{C}, 7^{\circ} \mathrm{C}\right.$ dan suhu kamar) pada varietas Tawang Mangu selama umur penyimpanan 0BSS dan 1BSS

\begin{tabular}{lccc}
\hline \multicolumn{1}{c}{ Perlakuan } & KA 0BSS $(\%)$ & KA 1BSS $(\%)$ & Susut KA 1BSS $(\%)$ \\
\hline Tawang Mangu, suhu $0^{\circ} \mathrm{C}$ & 60.03 & 34.13 & 43.15 \\
Tawang Mangu, suhu $7^{\circ} \mathrm{C}$ & 60.99 & 33.35 & 45.31 \\
Tawang Mangu, suhu ruang & 60.43 & 35.05 & 41.99 \\
\hline
\end{tabular}

Keterangan : BSS = bulan setelah simpan, $\mathrm{KA}=$ kadar air

Tabel 2. Persentase susut bobot perlakuan suhu penyimpanan $\left(0^{\circ} \mathrm{C}, 7^{\circ} \mathrm{C}\right.$ dan suhu kamar) pada varietas Tawang Mangu selama umur penyimpanan 0BSS dan 1BSS

\begin{tabular}{lccc}
\hline \multicolumn{1}{c}{ Perlakuan } & Bobot awal simpan $(\mathrm{g})$ & Bobot 1 BSS $(\mathrm{g})$ & Susut bobot $(\%)$ \\
\hline Tawang Mangu, suhu $0^{\circ} \mathrm{C}$ & 150.39 & 148.76 & 1.08 \\
Tawang Mangu, suhu $7^{\circ} \mathrm{C}$ & 150.047 & 138.14 & 7.93 \\
Tawang Mangu, suhu ruang & 150.061 & 137.37 & 8.45 \\
\hline
\end{tabular}

Keterangan : $\mathrm{BSS}=$ bulan setelah simpan, $\mathrm{KA}=$ kadar air

Tabel 3. Rata-rata daya tumbuh, tinggi tanaman dan jumlah daun bawang putih varietas Tawang Mangu untuk perlakuan $0^{\circ} \mathrm{C}, 7^{\circ} \mathrm{C}$ dan suhu kamar pada umur 1 bulan setelah tanam (BST)

\begin{tabular}{lccc}
\hline \multicolumn{1}{c}{ Perlakuan } & Daya tumbuh $(\%)$ & Tinggi tanaman $(\mathrm{cm})$ & Jumlah daun \\
\hline Tawang Mangu, suhu $0^{\circ} \mathrm{C}$ & 83.33 & 19.48 & 4.00 \\
Tawang Mangu, suhu $7^{\circ} \mathrm{C}$ & 77.77 & 17.12 & 4.00 \\
Tawang Mangu, suhu ruang & 56.94 & 7.15 & 4.00 \\
\hline
\end{tabular}


Tabel 4. Karakter rata-rata jumlah umbi, bobot total umbi dan jumlah umbi tunggal bawang putih varietas Tawang Mangu setelah umur 3 bulan setelah tanam

\begin{tabular}{lccc}
\hline \multicolumn{1}{c}{ Perlakuan } & Jumlah umbi & Bobot total umbi $(\mathrm{g})$ & Jumlah umbi tunggal \\
\hline Tawang Mangu, suhu $0^{\circ} \mathrm{C}$ & 11.00 & 9.70 & 3.00 \\
Tawang Mangu, suhu $7^{\circ} \mathrm{C}$ & 9.00 & 10.39 & 5.67 \\
Tawang Mangu, suhu ruang & 2.33 & 1.00 & 9.56 \\
\hline
\end{tabular}

Tabel 5. Karakter panjang umbi, diameter umbi, bobot per umbi dan jumlah siung per umbi bawang putih varietas Tawang Mangu setelah umur 3 bulan setelah tanam

\begin{tabular}{lcccc}
\hline \multicolumn{1}{c}{ Perlakuan } & Panjang umbi $(\mathrm{cm})$ & Diameter umbi $(\mathrm{cm})$ & Bobot per umbi $(\mathrm{g})$ & Jumlah siung \\
\hline Tawang Mangu, suhu $0^{\circ} \mathrm{C}$ & 1.61 & 1.74 & 1.68 & 4 \\
Tawang Mangu, suhu $7^{\circ} \mathrm{C}$ & 1.59 & 1.67 & 1.54 & 4 \\
Tawang Mangu, suhu ruang & 1.55 & 1.5 & 1.2 & 3 \\
\hline
\end{tabular}

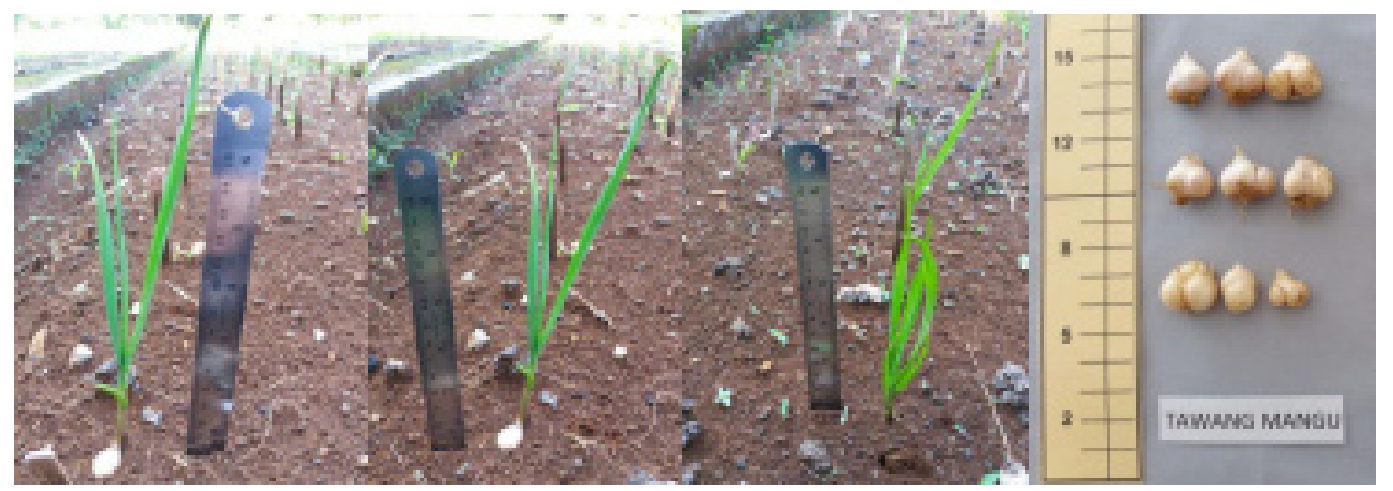

Gambar 1. Keragaan varietas Tawang Mangu umur 1 BST setelah penyimpanan 1 BSS pada suhu $0^{\circ} \mathrm{C}(\mathrm{A})$, suhu $7^{\circ} \mathrm{C}(\mathrm{B})$, suhu ruang $(\mathrm{C})$ dan ukuran umbi bawang putih varietas Tawang Mangu umur panen 3 bulan setelah tanam

\section{KESIMPULAN}

Penurunan kadar air selama satu bulan di dalam ruang pendingin tanpa tutup plastik hitam (under light condition) dapat mencapai $40-45 \%$ dan penurunan susut bobot mencapai 1-8\%. Tingkat kerusakan fisik tidak lebih dari 10$15 \%$. Varietas Tawang Mangu setelah penyimpanan di $0^{\circ} \mathrm{C}$ selama satu bulan menunjukan daya tumbuh tinggi (83.33\%) dan menghasilkan jumlah umbi lebih banyak (11 buah), sedangkan pada penyimpanan suhu ruang menunjukan daya tumbuh yang rendah (56.94\%) dan menghasilkan jumlah umbi yang sedikit (2-3 umbi). Penyimpanan $0^{\circ} \mathrm{C}, 7^{\circ} \mathrm{C}$ dan suhu ruang tetap menghasilkan bawang tunggal/bawang lanang. Kondisi umbi normal pada ketiga suhu menghasilkan ukuran umbi yang kecil dengan bobot 1-2 g, panjang umbi 1.5-1.7 cm, dan diameter umbi 1.5-1.6 cm, sehingga bawang putih cocok ditanam pada lahan yang subur.

\section{UCAPAN TERIMA KASIH}

Ucapan terimakasih disampaikan kepada Kementerian Riset, Teknologi dan Perguruan Tinggi melalui pendanaan penelitian Strategis Nasional.

\section{DAFTAR PUSTAKA}

[ASEAN] Association of South East Asian Nations. 2009. Asean Standard For Garlic (ASEAN Stan13:2009). http://www.asean.org/storage/images/archive/ AMAF\%2031\%20asean\%20standard20\%garlic.pdf [August, 6, 2018]

Brewster, J.L. 2008. Onions and Other Vegetable Alliums $2^{\text {nd }}$ Edition. Crop Production Science Horticulture 15. CABI, United Kingdom. 432 pp.

C. Medina, J.D.L., H.S. Garcia. 2007. Garlic: Post-harvest Operations. Post Harvest Compendium. Food and Agriculture Organization of The United Nation. $43 \mathrm{pp}$.

D. Hurtado, M.B., H. Ocampo, J.A., B. Pacheco, A., B. Rosa, A.P., M. Silva, E.M. 2015. Low temperature conditioning of garlic (Allium sativum L.) "seed" cloves induces alterations in sprouts proteome. Frontiers in Plant Science 6 (332):1-15. 
Hernawan U.E., A.D. Setyawan. 2003. Review : Senyawa Organosulfur Bawang Putih (Allium sativum L.) dan Aktivitas Biologinya. Biofarmasi 1(2):65-76.

Hughes, J., A.Collin H., A. Tregova, A.B. Tomsett, R. Cosstick, G. Jones M. 2006. Effect of Low Storage Temperature on Some of the Flavour Precursors in Garlic (Allium Sativum). Plant Foods for Human Nutrition 61: 81-85

Ichikawa, M., N. Ide, K. Ono. 2006. Changes in organosulfur compounds in garlic cloves during storage. J. Agric. Food Chem. 54: 4849-4854.

[Kementan] Kementerian Pertanian. 2018. Basis Data. http:// database.pertanian.go.id/eksim2012/hasilImporHs. php [24 Juli 2018].

Kabar Bisnis. Percepatan swasembada bawang putih, Mentan minta tambahan budget Rp1 triliun. http:// www.kabarbisnis.com/read/2876287/percepatanswasembada-bawang-putih-mentan-mintatambahanbudget-rp1-triliun [3 Juli 2017].
Palungkun, R., A. Budiarti. 1992. Bawang putih dataran rendah. Penebar Swadaya. 74 hal.

Resende, J.T.V., R.G.F. Morales, F.V. Resende, M.V. Faria, R.J. Souza, A. Marchese. 2011. Garlic Vernalization and Planting Dates in Guarapuava. Horticultura Brasileira 29: 193-198.

Sadjad, S. 1993. Dari Benih Kepada Benih. Grasindo. Jakarta (ID): 152 .

Volk, G.M., K.M. Rotindo. 2004. Low-temperature storage of garlic for spring planting. Hortscience 39(3):571573.

Wallace, I., K. Bezilla, L. Dermer. 2012. Garlic and Perennial Onion Growing Guide Southern Exposure Seed Exchange. in J. M. Cormack. Southern Exposure Seed Exchange, www.SouthernExposure.com PO Box 460 Mineral, VA. www.southernexposure.com/ growing-guides/allium-guide-web.pdf [2 September 2019]. 